\title{
Totális laparoszkópos hysterectomia az arteria uterinák eredésüknél történő ellátásával
}

\author{
Lampé Rudolf dr. ${ }^{1}$ - Móré Csaba dr. ${ }^{1}$ \\ Fazekas Ilona dr. ${ }^{2}$. Póka Róbert dr. ${ }^{1}$ \\ ${ }^{1}$ Debreceni Egyetem, Általános Orvostudományi Kar, Szülészeti és Nőgyógyászati Intézet, Debrecen \\ ${ }^{2}$ Kenézy Gyula Kórház és Rendelőintézet, Szülészeti és Nőgyógyászati Osztály, Debrecen
}

\begin{abstract}
Bevezetés: A méheltávolítás világszerte az egyik leggyakrabban végzett nőgyógyászati mưtét. A technikai fejlődésnek köszönhetően a laparoszkópos méheltávolítás egyre elterjedtebbé válik. A laparoszkópos mútétek nómenklatúrája nem egységes, de a totális laparoszkópos hysterectomia, amelynek lényege a teljes műtét endoszkópos úton történő elvégzése, kiemelkedik előnyeivel a többi mütéttípus közül. Amennyiben a totális laparoszkópos hysterectomiát az arteria uterinák eredésénél történő ellátásával együtt végezzük standardizált módszerrel, úgy a műtét biztonságossága, előnyei tovább növelhetők. Célkitüzés: Célunk volt saját eredményeink feldolgozása a szakirodalmi adatok ismertetésének fényében. Módszer: Műtéteinket az arteria uterinák eredésüknél történő ellátásával végeztük. Beválogatási kritériumok voltak a standardizált módszer alkalmazása, műtéti videofelvétel, pre- és posztoperatív vérképeredmények. Eredmények: Eredményeink igazolják az elfogadható mútéti időt, a minimális mütét alatti vérveszteséget, hospitalizációt és szövődményrátát. Következtetés: A totális laparoszkópos hysterectomia standardizált módszerének alkalmazása az arteria uterinák eredésüknél történő ellátásával gyakorlott kezekben, megfelelő anatómiai ismeretek birtokában egy kifejezetten biztonságos, reprodukálható technika, ami a laparoszkópos mútétek nyújtotta előnyöket maximálisan kihasználja. Orv. Hetil., 2017, 158(8), 298-303.
\end{abstract}

Kulcsszavak: totális laparoszkópos hysterectomia, arteria uterina, endoszkópia, standardizált mútéttechnika

\section{Total laparoscopic hysterectomy with the coagulation of the uterine arteries at their origin}

Introduction: Hysterectomy is one of the most frequently performed gynecological operations worldwide. Due to patient perceived advantages of technical development laparoscopic hysterectomy has become a widely used method. The attitude of patients, surgeons and service providers to laparoscopic procedures is not uniform, but total laparoscopic hysterectomy has prevailed due to its advantages from other types of laparoscopic hysterectomies. Coagulation of the uterine arteries at their origin during the standardized method of total laparoscopic hysterectomy provides further benefits for this procedure. Aim: Our aim was the presentation of our experience together with a review of the relevant literature. Method: Operations were performed with the coagulation of the uterine arteries at their origin right at the beginning of the procedure. Inclusion criteria were the use of the standardized method, video documentation of the surgery, and pre- and postoperative haemostatus results. Results: Our results confirm that the procedure involves an acceptable operating time that is comparable to that of open abdominal and vaginal hysterectomies, minimal blood loss that is far less than that in open procedures, a much shorter duration of hospitalization and a low complication rate. Conclusion: In skilled hands with proper knowledge of the anatomy the standardized method of total laparoscopic hysterectomy with the coagulation of the uterine arteries at their origin is a safe and reproducible technique which suitably utilizes the advantages of minimally invasive surgery.

Keywords: total laparoscopic hysterectomy, uterine artery, endoscopy, standardized method

Lampé, R., Móré, Cs., Fazekas, I., Póka, R. [Total laparoscopic hysterectomy with the coagulation of the uterine arteries at their origin]. Orv. Hetil., 2017, 158(8), 298-303.

(Beérkezett: 2016. november 16.; elfogadva: 2016. december 13.) 


\section{Rövidítések}

IP = infundibulopelvicum; LAVH = laparoszkóppal asszisztált vaginalis hysterectomia; $\mathrm{LH}=$ laparoszkópos hysterectomia; LSH = laparoszkópos szubtotális hysterectomia; TLH - totális laparoszkópos hysterectomia

A méheltávolítás az egyik leggyakrabban végzett mútét világszerte $[1]$. Technikáját tekintve számos változat ismert: laparotomiából végezhető (abdominalis hysterectomia, abdominalis supracervicalis hysterectomia) és minimálisan invazív technikák (vaginalis hysterectomia, laparoszkóppal asszisztált vaginalis hysterectomia és laparoszkópos hysterectomia). Ezek indikációs köre alapvetően különböző, de átfedéseket is tartalmaz, emiatt a mûtétet végző orvos választhat a különböző eljárások közül. Napjainkban az a nézet az elfogadott, hogy a beteg számára a hüvelyi méheltávolítás a legkevésbé megterhelő, emiatt elsőként választandó, ezt követi a laparoszkópos út, és ennek kivitelezhetetlensége esetén végzendő hasi méheltávolítás $[2,3]$.

A laparoszkópos eljárás előnyeihez soroljuk a műtét alatti nagyított képet, a jobb hozzáférést a környező szervekhez (ureter, húgyhólyag, rectum, az iliacalis erek), a precízebb haemostasist. Emellett a páciens szempontjából elónyös a rövidebb hospitalizáció, a kisebb hasi incisio, következményes posztoperatív fájdalom, a kevesebb vérvesztés, kisebb infekciós rizikó és ritkább posztoperatív ileus $[4,5]$.

A minimálisan invazív mútéti technika hátrányai között döntően olyan szempontok szerepelnek (az operatív készségek elsajátításának időigényes volta, az eszközök költsége, a hosszabb múttéti idő), amelyek kivétel nélkül cáfolják önmagukat, hiszen a nyílt mútétek technikáját is évek alatt sajátítják el a gyakorlatlan az operatôrök, az eszközök költsége egyszeri nagyobb kiadást takar és hosszú távon olcsóbbá teheti a kórházi kiadásokat, nem beszélve a rövidebb betegállományban töltött időrôl.

A laparoszkópos hysterectomiák feldolgozása és eredményeinek objektív összehasonlítása nehézségekbe ütközik a nem egységes nómenklatúra, a létező standardizált módszerek ellenére nem egységes technikai kivitelezés miatt [6].

A laparoszkópos úton végzett méheltávolításokat alapvetően a következő csoportokba oszthatjuk: diagnosztikus laparoszkópia vaginalis hysterectomiával, laparoszkóppal asszisztált vaginalis hysterectomia (LAVH), laparoszkópos szubtotális hysterectomia (LSH), laparoszkópos hysterectomia $(\mathrm{LH})$ és totális laparoszkópos hysterectomia (TLH) [7-9]. Ezek közül a diagnosztikus laparoszkópia vaginalis hysterectomiával és a LAVH leginkább a tanulási fázis részeként említhetô meg, bár a LAVH elfogadottsága nemzetközileg jelentős, hiszen nem igényel akkora technikai tudást, mint a TLH [6]. A LAVH lényegében hüvelyi méheltávolítás, ahol a ligamentum rotundum és az ovariumok tartószalagjainak dissectióját laparoszkópos úton biztosítják, majd a múté- tet hüvelyi úton fejezik be. Nincs elfogadható szakirodalmi adat arra vonatkozóan, hogy a LAVH-nak előnyei lennének a TLH-val szemben [4]. Ugyanúgy ellentmondásos a mútétet végző orvosok között az LSH megítélése, bár a szakirodalmi adatok ennél tisztább képet adnak. Az LSH lényege, hogy az uterus corpusát a belső méhszáj magasságában amputálják, az uterust colpotomián át vagy morcellálással távolítják el a beteg testéból. Egyedüli bizonyított előnyként a rövidebb mútéti idő említhető az LSH mellett, de hátrányainak száma jóval több. Ciklikus vérzés jelentős százalékban fordul elő a mútétet követően. Előfordulhat a cervixcsonk necrosisa, cervixcarcinoma kialakulása, amelyek egy későbbi trachelectomia lehetőségét rejtik magukban [6]. Már 2007-ben megjelent egy ajánlás az Amerikai Szülész-Nőgyógyász Társaságtól, ami megfogalmazza, hogy az LSH-t nem lehet ajánlani a TLH-nál jobb módszerként. Mindezt arra alapozzák, hogy a perioperatív morbiditásban nem bizonyítottan jobb az LSH, és szintén nincs alátámasztva, hogy a posztoperatív vizeletürítési képesség vagy szexuális aktivitás bármelyik más módszernél jobb eredményt adna. Nem különbözik a két módszer eredménye a betegek által megítélt életminőségben és testképben sem [10]. A TLH definíciója az, hogy a teljes mútét laparoszkópos úton történik. Ha a mútét bármelyik pontján eltérünk a laparoszkópos módszertől, akkor a mútétet nem lehet TLH-nak nevezni, hanem LH-nak nevezzük. Sajnálatos módon a témával foglalkozó irodalom sem egységes a megnevezést illetően, de a technikai és személyi fejlődéssel - mivel egyre több intézetben végzik a TLH-t - egyre gyakrabban találkozhatunk a pontos elnevezésekkel. Bár a nőgyógyászat nemzetközileg is nehezen adoptálta a laparoszkópos technikát, amelynek okaként a nehezen hozzáférhető képzést, az eleinte hoszszú mútéti időt, a drága múszerparkot és a módszertôl való idegenkedést említhetjük, ahogy egyre több nőgyógyász tud TLH-t végezni, a módszer növekvő mértékben veszi át a hasi méheltávolítás szerepét $[6,11]$. Jól példázza a fentieket, hogy olyan magyar nyelvú közlemény sem született még, ami az elvégzett laparoszkópos hysterectomiák eredményeit ismertetné, bár laparoszkópos hysterectomiát már számos hazai kórházban végeznek.

A TLH-mútétnek abszolút kontraindikációja nincs. Relatív kontraindikációk közé soroljuk az uterus extrém nagy méretét, a jelentősen csökkent mobilitását, a mütétet végző tapasztalatát, az előzményben szereplő többszörös laparotomiát és a 30 feletti testtömegindexet (aneszteziológiai problémák és a pneumoperitoneum fenntartásának nehezítettsége miatt) [12]. A mútét komplikációi megegyeznek az egyéb laparoszkópos mútétek komplikációival mind jellegükben, mind arányukban. Meg kell említeni a portok behelyezésének komplikációit (vérzés, nagyérsérülés, bélsérülés, infekció, herniatio), a mútét során az ureterek, nagyerek és húgyhólyag sérüléseit [6]. Az utóbbi időben egyre elterjedtebb az endoszkópos beavatkozások kapcsán az az igény, 
hogy az operáló orvos a megfelelő mütéttechnikai szabályokat, módszereket alkalmazza, így nagyobb eséllyel operál komplikációk nélkül. Ebből következik, hogy az operáló orvos nem a komplikációk ellátásában lesz jártas, hanem a komplikációkat megelőzi a megfelelő mútéttechnika alkalmazásával. Ha mégis megtörténik, akkor elvárás lehet, hogy azt azonnal ismerje fel [12]. Általánosan elmondható, hogy egy mútét komplikációinak minimálisra csökkentését a standardizált lépések biztosítják. A TLH-nak is létezik standardizált módszere, aminek célja a műtét biztonságosságának maximálisra növelése és reprodukálhatósága.

A TLH-mütét kritikus jelentőségű pontja az uterinalis erek ellátása. Az arteria uterina ascendens és descendens ágainak oszlása előtti, azaz a retroperitoneumban történő ellátása elengedhetetlen feltétele a TLH-nak, ebből következik, hogy ez a lépés a retroperitoneum ismeretét is igényli [4]. Éppen ezért az a módszer, amely során az uterus oldalsó falához közel (ahol ráadásul az uterus vénás hálózata is található), a ligamentum latum kettőzetének dissectióját követően, a belső méhszáj magasságában, a konvencionális laparotomiánál alkalmazotthoz hasonló módon, az uterinalis erek ágainak koagulálása sem a biztonságosság igénye, sem a standardizált módszer szempontjából nem elfogadható. Ezen túlmenően ez a módszer foóként nagyobb uterus esetén kihívást jelenthet, ugyanis az ureter az isthmushoz 5-7 mm-re helyezkedik el, azaz ebben a régióban az extenzív koaguláció (ami ennek a módszernek az alkalmazásával várható) miatt az ureterek sérülésének a veszélye jelentősen fokozódik [13]. Szakirodalmi adatokkal alátámasztott módszer az arteria uterina eredésénél történő ellátása, ami hatékony és biztonságos, mivel ellátását követően jelentősebb vérzésre nem kell számítanunk, és az intraoperatív vérvesztés is kevesebb, valamint a módszer a TLH standardizált lépéseibe könnyen beilleszthető [13, 14].

Munkánk célja volt azon TLH-mütéteink eredményeinek feldolgozása, ahol az arteria uterinát annak arteria iliaca internából történő eredésénél koaguláltuk.

\section{Módszer}

A vizsgálathoz betegbeválogatási kritériumaink voltak: a TLH standardizált módszerének alkalmazása, az arteria uterina eredésénél történő koagulációja, pre- és posztoperatív vérképvizsgálat, valamint a mütét teljes egészének rögzítése. A páciensek preoperatív kivizsgáláson estek át, mütét előtt 12 órával nem fogyasztottak szájon át semmit. Intraoperatív antibiotikum-profilaxist és posztoperatív trombózisprofilaxist (alacsony molekulasúlyú heparin) alkalmaztunk. A mútétek intratrachealis narkózisban történtek, a betegeket lithotomiás pozícióban helyeztük el. Állandó hólyagkatétert használtunk, amit a mütét utáni reggelen távolítottunk el. Minden esetben használtunk uterusmozgatót, illetve hüvelyi obturatort, aminek a közepén lévő nyársa a nyakcsatornába rögzíthető volt. A $10 \mathrm{~mm}$-es optikai trokárt a köldökön ke- resztül vezettük a hasüregbe, direkt behatolással, majd három $5 \mathrm{~mm}$-es behatoláson keresztül vezettük be az eszközöket (bipoláris koagulálóeszköz, ultrahangos koaguláló-vágó eszköz és atraumatikus fogó). Ezek elhelyezése a középvonalban, $3 \mathrm{~cm}$-rel a symphisis felett, valamint bal és jobb oldalon, $2 \mathrm{~cm}$-rel a spina iliaca anterior superior felett történt. Az intraabdominalis nyomás 15 Hgmm volt, $12-15^{\circ}$-os Trendelenburg-pozícióban. A mútét a kismedencei szervek, majd a felhas megfigyelésével kezdődött. Ezt követően a kismedencéből eltávolítottuk a vékonybeleket, illetve a szigmabél bal oldali, fiziológiás medencefali kitapadását szükség esetén oldottuk. A további lépések kisebb módosításokkal a korábban ismertetett, standardizált technikával történtek $[4,12]$. Jobb és bal oldalon koaguláltuk és átvágtuk a ligamentum rotundumot, majd a peritoneumot meghasítottuk a ligamentum infundibulopelvicummal (IP) párhuzamosan. Azonosítottuk az arteria és vena iliaca externát, majd az arteria hypogastricát és az uretert. Feltártuk a paravesicalis és pararectalis teret, majd felkerestük az arteria uterina eredését, amit bipoláris eszközzel koaguláltunk, majd átvágtunk (1. ábra). A ligamentum latum hátsó lemezén, az ureter felett, az IP-szalag alatt nyílást (úgynevezett ablakot) képeztünk, majd azt az IP-szalaggal párhuzamosan meghasítottuk. Ezzel az uretert eltávolítottuk a mútéti területról úgy, hogy az mindvégig látható maradt (2. ábra). A húgyhólyag megragadását és felemelését követően meghasítottuk a mellső áthajlási redőt, majd a húgyhólyagot mobilizáltuk, letoltuk. Meghasítottuk a peritoneumot a sacrouterin szalagok tapadásának magasságában. A beteg életkorától függően (ha több mint 50 éves volt) koaguláltuk és átvágtuk az IPszalagot. Ha ez nem volt indokolt, akkor a ligametum ovarii propriumot vágtuk át. Minden mütét során eltávolítottuk a méhkürtöket, a mesosalpinx átvágásával az ajánlásoknak megfelelően [15]. Bal és jobb oldalon átvágtuk a ligamentum cardinalékat. Monopoláris hook segítségével körkörös boltozati metszést ejtettünk. A speciment a hüvelyen keresztül távolítottuk el. A hüvelycsonkot nyolcas öltésekkel zártuk, extracorporalis csomózási technikával, l-es felszívódó fonállal, a vesicovaginalis fascia és a sacrouterin szalagok felöltésével, a későbbi csonkprolapsus megelőzése céljából. Drént csak indokolt esetben hagytunk a hasüregben, azt a mútétet követő nap reggelén távolítottuk el. Hasưri mosást csak a hüvelycsonk zárását követően végeztünk. A posztoperatív vérképvizsgálat a mútétet követő nap reggelén történt. A pre- és posztoperatív laborvizsgálatok, valamint a mütétről készült videofelvétel értékelésével a mütéti időt, a hemoglobin- és hematokritkülönbséget, az intraés posztoperatív komplikációkat, a konverziós rátát és a hospitalizációs időt elemeztük.

\section{Eredmények}

A Debreceni Egyetem Szülészeti és Nőgyógyászati Klinikáján 2015 januárjától 2016 novemberéig 57, a bevá- 


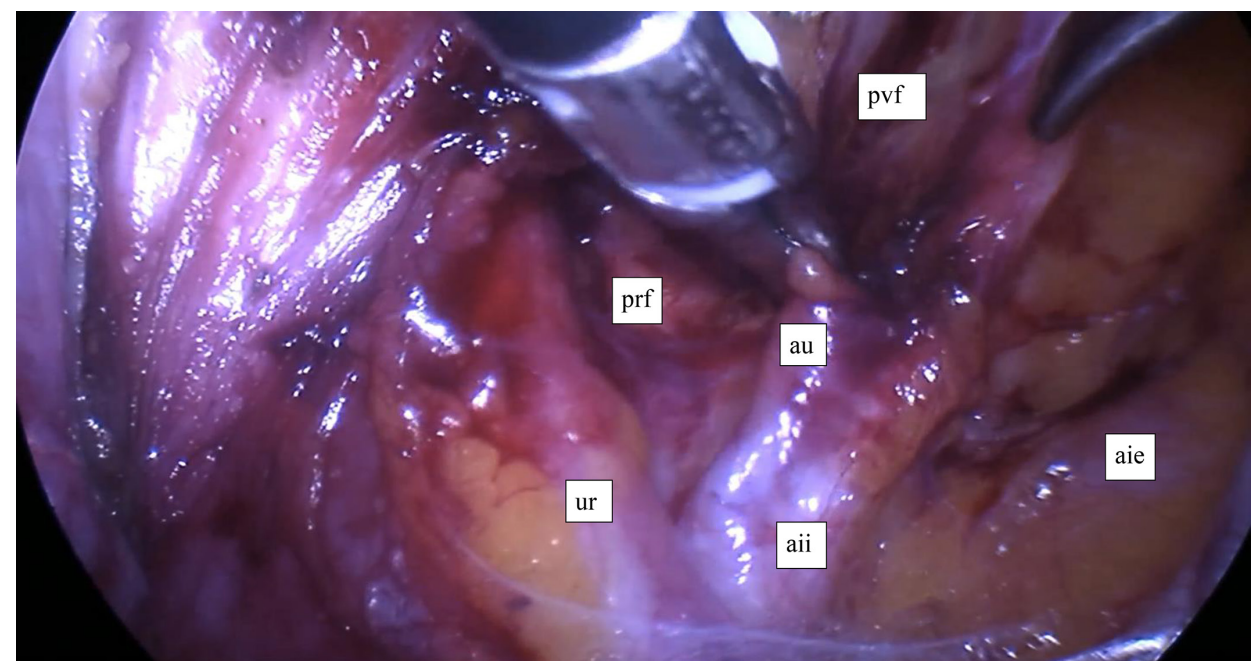

1. ábra


2. ábra

$$
\begin{aligned}
& \text { A ligamentum latum lemezén úgynevezett ablak képzése } \\
& \text { ip = ligamentum infundibulopelvicum; ov = ovarium; ur = ureter; ut = uterus }
\end{aligned}
$$

logatási kritériumoknak megfelelő mütétet végeztünk. A mütétek indikációinak megoszlását az 1 . táblázat mutatja. Látható, hogy a mútétek közel $80 \%$-ának indikációja a myomás uterus és a konzervatív kezelésre nem szûnő vérzészavar. A betegek adatait és a mütétek ered-

1. táblázat |A mútéti indikációk megoszlása

\begin{tabular}{lcc}
\hline Indikáció & Betegszám & Százalék \\
\hline Myoma uteri & 34 & 59,6 \\
Abnormális uterinalis vérzés* & 12 & 21,1 \\
In situ cervixcarcinoma & 6 & 10,5 \\
Adenomyosis & 2 & 3,5 \\
Onkológiai javallat & 2 & 3,5 \\
Conglutinatio cervicis uteri & 1 & 1,8 \\
\hline
\end{tabular}

*Terápiarezisztens esetek. ményeit a 2. táblázat mutatja. Intraoperatív szövődmény nem volt. Az 57 betegen felül három esetben diagnosztikus laparoszkópiát követően konvertáltunk hasi mütétre, aminek oka mindhárom esetben a súlyos obesitas $\left(\mathrm{BMI}>35 \mathrm{~kg} / \mathrm{m}^{2}\right)$ volt, magyarázata pedig a korlátozott látási viszonyok, az aneszteziológiai szempontból nehezen kivitelezhető Trendelenburg-pozíció, valamint a nehezen fenntartható pneumoperitoneum voltak. Két esetben volt posztoperatív szövődményünk. Egyik esetben a hüvelycsonkból származó vérzést a negyedik posztoperatív napon intravénás narkózisban elektromos kaccsal elláttuk. A másik esetben a hüvelycsonk infekciója és láz miatt újabb laparoszkópiát végeztünk a 10. posztoperatív napon. Ennek során a hüvelycsonk feletti letokolt folyadékgyülemet felszabadítottuk, a hasüreget átöblítettük, majd széles spektrumú intravénás antibiotikum-kúrát követően a 14. posztoperatív napon a beteg tünet- és panaszmentessé vált. 
2. táblázat $\mid$ A mútéten átesett betegek $(\mathrm{n}=57)$ klinikai adatai és a mútétek eredményei

\begin{tabular}{ll}
\hline & Eredmények \\
\hline Életkor $(\text { év })^{*}$ & $45,4 \pm 12,5$ \\
BMI $\left(\mathrm{kg} / \mathrm{m}^{2}\right)^{*}$ & $25,83 \pm 3,51$ \\
Mútéti idő $(\text { perc })^{* *}$ & $95,5(51-207)$ \\
Hemoglobincsökkenés $(\mathrm{g} / \mathrm{L})^{*}$ & $15,62 \pm 7,77$ \\
Hematokritcsökkenés* & $0,05 \pm 0,02$ \\
Uterus tömege $(\mathrm{g})^{*} *$ & $75(41-430)$ \\
Hospitalizáció $\left(\right.$ nap ${ }^{*}$ * & $2,31(2-4)$ \\
Intraoperatív szövődmény & 0 \\
Posztoperatív szövődmény & 2 \\
\hline
\end{tabular}

*Az értékek átlagot jelölnek \pm szórás.

**Az értékek átlagot jelölnek (szélső értékek).

\section{Megbeszélés}

Az arteria uterinák lezárásáról először Ravina és mtsai számoltak be 1995-ben panaszokat okozó myomás uterus kapcsán, kedvező eredménnyel [16]. Később a módszert más nőgyógyászati mûtétek alkalmával is használták, legyen ez az arteria uterinák átmeneti vagy végleges elzárása. A laparoszkóppal végzett myomamútétek első lépéseként történő mindkét oldali arteria uterina elzárása a tünetek jelentős csökkenéséhez vezetett [17]. TLH során is ismert a kétoldali arteria uterina elzárása a mútét kezdetén. Egyes szerzők eredményei szerint az így végzett TLH-mútét gyorsabb a más módon végzett TLHmütéteknél, a vérveszteség kevesebb és a hospitalizációs idő rövidebb [18-20]. Ezekből a közleményekből nem derül ki pontosan, hogy a TLH-mútétet milyen módszerrel végezték (standardizált vagy nem), így azok egymással való összehasonlítása nehézségekbe ütközik.

A „laparoszkópos hysterectomia” elnevezés számos mütéttípust foglal magában a laparoszkópos adhaesiolysist követő vaginalis hysterectomiától a teljes egészében laparoszkóppal végzett beavatkozásig [21]. Ennek köszönhetően elfogadható az igény a különböző eljárások pontos megnevezésére, ezáltal a különböző műtéttechnikák precíz leírására, aminek segítségével ezen mútétek egymással összehasonlíthatóvá válnak. A laparoszkópos hysterectomiák közül kiemelkedik a TLH, mint a legbiztonságosabb mútéttechnika, ami egyúttal a legnagyobb technikai tudást is igényli [4]. Mind a műtétet végző orvos, mind az egyre tájékozottabb betegek részéról növekvő igény mutatkozik a TLH alkalmazására. Amennyiben a TLH során az arteria uterinát eredésénél látjuk el, amellett, hogy a mútét biztonságosságát fokozzuk, a mütétet végző orvos jobban fog tájékozódni a kismedencei retroperitoneumban, ami kifejezett előnyére válhat a komplikáltabb vagy kiterjesztett mútétek során. Emellett az ureterek látótérbe hozása és az úgynevezett ablak képzése is növeli a műtét biztonságosságát, mivel az ureter sérülésétől való félelem leginkább a hiányos anatómiai ismeretekkel magyarázható. Az uterusmozgatóval és a latum lemezén az ablak képzésével, valamint a hólyag dissectiójával az ureterek sérülésének esélye elhanyagolható. Persze az optimális feltételekhez hozzátartozik a mütői team (operáló orvos, asszisztens, másodasszisztens, aneszteziológus és a műszerelő) összeszokottsága és képzettsége, ugyanis a TLH előnyei elsősorban gyakorlott kezekben mutatkoznak meg $[7,8$, 12]. A technikai kompetenciához szükséges beavatkozások száma 20-30 közöttire tehető. Ez az a mütéti szám, amelynek során a mútéti idő és a komplikációk számának progresszív csökkenése figyelhető meg [22]. Egy másik megfogalmazás szerint a tanulófázisnak addig kell tartania, amíg a mütétet végző orvos a mütéti technikát standardizált módszerrel el tudja végezni [21]. A standardizált mütéttechnika alkalmazása tehát alapvető kívánalom a betegek biztonságának, a kedvező perioperatív eredményeknek az érdekében. Az arteria uterinák eredésüknél való ellátása csökkenti a vérveszteséget, a mütét későbbi szakaszában a vérzéssel kapcsolatos szövődmények esélyét, valamint a mütéti időt. A pre- és posztoperatív hemoglobinszintek értékelésénél figyelembe kell venni a hatályos aneszteziológiai irányelveknek megfelelő, mütétek alatti és a másnap reggelig alkalmazott jelentős folyadékterápiát. A 3-4 liter infúzió jelentős haemodilutiót okoz és a vizsgálatunkban kimutatott vérképváltozás nagyobb részben ennek köszönhető. Ahogy a mütétet végző orvos gyakorlottá válik a technikában, illetve a retroperitoneum ismeretében, úgy az arteria uterina eredésének kipreparálásához szükséges idő is jelentősen csökken [23]. Eredményeinkből látható, hogy a mútétek minimális szövődményrátával, elfogadható időn belül, minimális vérveszteséggel és hospitalizációs idővel elvégezhetők. Tehát a szakirodalmi eredményeket alátámasztva, a TLH minden előnye igazolható.

\section{Következtetés}

Elmondható, hogy a TLH az arteria uterinák eredésüknél történő ellátásával egy biztonságos, reprodukálható technika, ami gyakorlott kezekben, megfelelő anatómiai ismeretek birtokában, hatékonyan ötvözi a laparoszkópos technika jól ismert előnyeit.

Anyagi támogatás: A közlemény megírása anyagi támogatásban nem részesült.

Szerzői munkamegosztás: L. R.: A közlemény megírása, irodalomkutatás, mútétek elvégzése, a vizsgálat koordinációja. M. Cs.: A vizsgálat lefolytatása, a mútétek elvégzése. F. I.: Irodalomkutatás, hipotézisek kidolgozása, adatok feldolgozása. P. R.: A vizsgálat felügyelete, mütétek elvégzése. A cikk végleges változatát valamennyi szerzője elolvasta és jóváhagyta.

Érdekeltségek: A szerzőknek nincsenek érdekeltségeik. 


\section{Irodalom}

[1] Drahonovsky, J., Haakova, L., Otcenasek, M., et al.: A prospective randomized comparison of vaginal hysterectomy, laparoscopically assisted vaginal hysterectomy, and total laparoscopic hyster ectomy in women with benign uterine disease. Eur. J. Obstet. Gynecol. Reprod. Biol., 2010, 148(2), 172-176.

[2] American College of Obstetricians and Gynecologists: ACOG Committee Opinion No. 444: choosing the route of hysterectomy for benign disease. Obstet. Gynecol., 2009, 114(5), 11561158.

[3] AAGL Advancing Minimally Invasive Gynecology Worldwide AAGL position statement: route of hysterectomy to treat benign uterine disease. J. Minim. Invasive Gynecol., 2011, 18(1), 1-3.

[4] Reich, H.: Total laparoscopic hysterectomy: indications, techniques and outcomes. Curr. Opin. Obstet. Gynecol., 2007, 19(4), 337-344.

[5] Langmár, Z., Szabó, I.: Role of laparoscopy in the treatment of early endometrial cancer. [A laparoszkópia szerepe a korai stádiumú méhtestrák sebészi kezelésében.] Orv. Hetil., 2010, 151(42), 1748-1752. [Hungarian]

[6] Elkington, N. M., Chou, D. A.: A review of total laparoscopic hysterectomy: role, techniques and complications. Curr. Opin. Obstet. Gynecol., 2006, 18(4), 380-384

[7] Garry, R., Reich, H., Liu, C. Y.: Laparoscopic hysterectomy definitions and indications. Gynaecol. Endosc., 1994, 3(1), 1-3

[8] Reich, H., Roberts, L.: Laparoscopic hysterectomy in current gynecological practice. Rev. Gynaecol. Pract., 2003, 3(1), 32-40.

[9] Sziller, P., Langmár, Z.: Novel laparoscopic techniques in gynecologic surgery. [Legújabb laparoszkópos technikák a nőgyógyászati sebészetben.] Orv. Hetil., 2011, 152(20), 785792. [Hungarian]

[10] American College of Obstetricians and Gynecologists: ACOG Committee Opinion No. 388 November 2007: supracervical hysterectomy. Obstet. Gynecol., 2007, 110(5), 1215-1217.

[11] Wright, J.: Innovation in minimal access surgery: changing the culture? Gynecol. Surg., 2005, 2(2), 81-82.

[12] Wattiez, A., Cohen, S. B., Selvaggi, L.: Laparoscopic hysterectomy. Curr. Opin. Obstet. Gynecol., 2002, 14(4), 417-422.
[13] Köhler, C., Hasenbein, K., Klemm, P., et al.: Laparoscopic-assisted vaginal hysterectomy with lateral transsection of the uterine vessels. Surg. Endosc., 2003, 17(3), 485-490.

[14] Kavallaris, A., Kalogiannidis, I., Chalvatzas, N., et al.: Laparoscopic-assisted vaginal hysterectomy with and without laparoscopic transsection of the uterine artery: an analysis of 1,255 cases. Arch. Gynecol. Obstet., 2011, 284(2), 379-384.

[15] Yoon, S. H., Kim, S. N., Shim, S. H., et al.: Bilateral salpingectomy can reduce the risk of ovarian cancer in the general population: A meta-analysis. Eur. J. Cancer., 2016, 55, 38-46.

[16] Ravina, J. H., Herbreteau, D., Ciraru-Vigneron, N., et al.: Arterial embolisation to treat uterine myomata. Lancet, 1995, 346(8976), 671-672.

[17] Liu, M., Cheng, Z., Dai, H., et al.: Long-term efficacy and quality of life associated with laparoscopic bilateral uterine artery occlusion plus partial resection of symptomatic adenomyosis. Eur. J. Obstet. Gynecol. Reprod. Biol., 2014, 176, 20-24.

[18] Kale, A., Aksu, S., Terzi, H., et al.: Uterine artery ligation at the beginning of total laparoscopic hysterectomy reduces total blood loss and operation duration. J. Obstet. Gynaecol., 2015, 35(6), 612-615.

[19] Lee, J. E., Kim, K. G., Lee, D. O., et al.: Ligation of uterine vessels in total laparoscopic hysterectomy using Hem-o-lok clips. Taiwan. J. Obstet. Gynecol., 2015, 54(1), 8-12.

[20] Poojari, V. G., Bhat, V. V., Bhat, R.: Total laparoscopic hysterectomy with prior uterine artery ligation at its origin. Int. J. Reprod. Med., 2014, 2014, 420926.

[21] Munro, M. G., Parker, W. H.: A classification system for laparoscopic hysterectomy. Obstet. Gynecol., 1993, 82(4), 624-629.

[22] Mavrova, R., Radosa, J. C., Wagenpfeil, G., et al.: Learning curves for laparoscopic hysterectomy after implementation of minimally invasive surgery. Int. J. Gynaecol. Obstet., 2016, 134(2), 225-230.

[23] Sinha, R., Sundaram, M., Nikam, Y. A., et al.: Total laparoscopic hysterectomy with earlier uterine artery ligation. J. Minim. Invasive Gynecol., 2008, 15(3), 355-359.

(Lampé Rudolf dr., Debrecen, Nagyerdei krt. 98., 4032 e-mail: rudolflampe@msn.com)

\section{A rendezvények és kongresszusok híranyagának leadása}

a lap megjelenése előtt legalább 40 nappal lehetséges, a 6 hetes nyomdai átfutás miatt. Kérjük megrendelőink szíves megértését.

A híranyagokat a következő címre kérjük:

Orvosi Hetilap titkársága: edit.budai@akademiai.hu

Akadémiai Kiadó Zrt. 